(C) 1982 ISIJ

\title{
焼結鉱組織と還元性状の関係
}

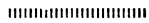

$$
\text { 佐藤 勝彦* · 鈴木 悟*2 } \text {. 沢村 靖昌 }{ }^{* 3} \cdot \text { 斧 勝也 }{ }^{* 4}
$$

\section{Relation between Sinter Microstructures and Sinter Properties during Reduction}

\author{
Katsuhiko SAtō, Satoru Suzuki, Yasumasa Sawamura, and Katsuya Ono
}

\begin{abstract}
Synopsis :
\end{abstract}
Evaluation of sinter properties during reduction has been studied by a new method on quantification of sinter microstructure (mineral components and porosity).

(1) Reduction degradation index is expressed by number of $100 \sim 300 \mu \mathrm{m}$ grain size of hematite.

(2) Reduction index is described by quantity of $\mathrm{Ca}$-ferrite and porosity consisted of pore size less than $150 \mu \mathrm{m}$.

(3) Pressure drop during softening test under load is indicated by quantity of slag and total porosity. The pressure drop increases with increasing slag quantity and decreasing the total porosity. ity.

(4) Tempcrature at beginning of melt-down is estimated by quantity of Ca-ferrite and total poros-

The above results are not only statistical, but also substantial because these are supported by investigation during reduction. So these are applied to indices of sinter evaluation.

\section{1. 緒言}

焼結鉱の品質はその構成鉣物之気孔構造, すなわち組 織で一義的に決まるものといえる。ところが従来，これ ら両者の関係を定星的に検謞した研究は少ない1)2). 焼結 鈗の構成鉱物そのものについての研究は数多く報告され

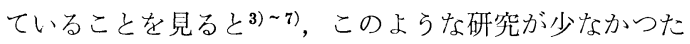
のは組織の定量化手段を欠いていたためと考兄られる。

もし燒結鉣の組織が迅速かつ定量的に把握できれば, 望ましい品質の焼結鉱イメージも明確になり，焼結鉱製 造に際して原料の選択や焼絬操業条件の決定に寄与する ところが大きい。

このため最近，焼結鉱の組織定量へも画像処理技術の 応用が試又られている8) 14). しかし現在のところいまだ 手法の開発や夹機烧絬鉱の测定に着手した段階で優良焼 結鉱のイメージを描くに到つていないように考兄られ る.

本報ではこのような現状を踏まえ，最近進歩の著しい 画像処理装置を用いて焼結鉱構成鉱物の自動分析を行
い,またいくつかの気孔構造の測定結果とあわせて, 焼 結鉱組織とその還元時の性状の関係について検討した. その結果，良好な還元性状を有するために焼結鉱の具備 すべき組織条件について，2，3の知見を得たので報告 する.

\section{2. 組 織 定 量 法}

\section{$2 \cdot 1$ 鉱物組成測定法の概要}

燒結鉱の構成鉱物はへマタイト，マグネタイト，カル シウムフェライトおよびスラグに大別される．これらの 鉱物は光学的性質が異なつていて, 顕微鏡下での反射輝 度レベルで識別できる．本報での測定方法は顕微鏡によ る 1 視野の反射光を 50 万個の画像素子 $(1.47 \mu \times 1.47$

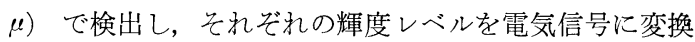
して計算機で解析するもので, 顕微鏡視野は自動焦点, 自動走查装置により迅速に設定できる。1 視野の測定時 間は約 $0.5 \mathrm{~s}$ である.

\section{2 自動鉱物組成分析装置のシステム構成}

Fig. 1 亿示すように自動分析装置は入力系, 画像処理 昭和 56 年 4 月本会講演大会にて発表 昭和 57 年 3 月 18 日受付 (Received Mar. 18, 1982)

* 新日本製鉄 (株) 生産技術研究所 (Process Technology R \& D Laboratories, Nippon Steel Corp., 1-1-1 Edamitsu Yawatahigashi-ku Kitakyushu 805)

*2 新日本製鉄 (株) 生产技術研究所（現：新日本製鉄 (株) 本社） (Process Technology R \& D Laboratories, Now Head Office, Nippon Steel Corp.)

*3 新日本製鉄 (株) 生应技術研究所（現：浜田重工(株) (Process Technology R \& D Laboratories, Nippon Steel Corp., Now Hamada Heavy Industries Ltd.)

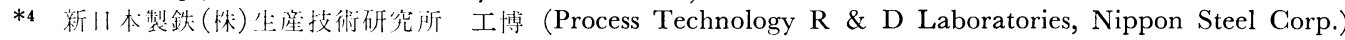




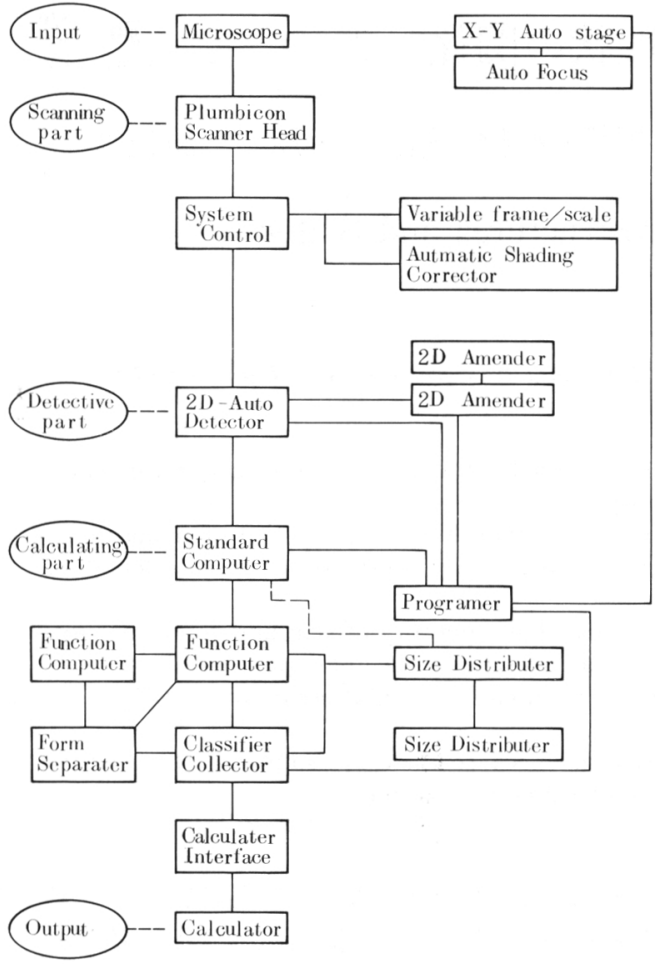

Fig. 1. System of the image analyser.

装置（QTM 720）抽び出力系で構成されている.

入力系は光学顕微鏡, 自動走査ステージ, 自動焦点調 整装置からなる.

画像処理装置は走査系, 検出系, 処理系に分けられ, それぞれ光学信号の電気信号への変換, アナログ信号の デジタル信号への変換, 抢よび計算機による処理の各機 能をもつている. したがつて走査系では光信号と電気信 号の広範囲にわたる線形性と光信号の均一性の維持が要 求される. 検出系では輝度レベルによる鉱物識別の際の 境界誤差が問題となる. これに対しては両輝度レベルの 中間点を境界とすることで解決している．また差異の大 きい輝度レベル境界に現れるハロー誤差は 2 次元画像修 正装置によりとり除いている，処理系では画素の輝度レ
ベルデータに基づいて画像の形態を定める．鉱物組成の 面積率のみでなく, 周長, 径, 個数などが測定でき,さ らに画像の修正として膨張, 侵食, 消去, 付加, 合体な どの機能をもつている. 出力系は計算機 (YHP) で記 録, 演算, 統計処理データの取捨選択がでさる.

\section{3 鉱物組成の測定方法}

試料として 15〜20 mm の焼結鉱を 4 個採取し，樹脂 埋め込夕研磨によつて測定面を作る. これを反射光下, 160 倍でそれぞれ 100 視野, 計 400 視野の測定を行う. 画像解析装置はまず均一輝度レベルで画面の均一性を調 整し, 次に焼結鉱試料によつてへマタイト, マグネタイ ト，カルシウムフェライト，スラグおよび気孔の 5 段階 の輝度を設定する.この輝度が安定しているか否かを 1 試料につき 5 視野を選んでチェックし，めらかじめ設定 したプログラムで自動分析する. Photo. 1 に焼結鉱の 組織検出像を示す.

\section{$2 \cdot 4$ 気孔率の測定方法}

画像処理でも気孔が 測定できるが，焼結鉱の場合形 状が複雑で 自動分析では気孔の認識が難しい。そこで 15 20 mm の焼結鉱 5 個を試料として次のような方法 で気孔率を測定した.

(1)水銀法 1 Torr まで減圧して水銀中に浸漬させ, 大気压に戻したとき水銀が浸入しなからた部分を焼結鉱 体積と見なして算出する気孔率 $\left(\varepsilon_{\mathbf{0}}\right)$ で，約 $7 \mu$ 以下の 開気孔十閉気孔が測定でさる.

(2)溶融パラフィン法 $\quad 80^{\circ} \mathrm{G}$ での溶融パラフィンに 浸積させて (1) と同様に算出する気孔率 $\left(\varepsilon_{1}\right)$ で, 約 500 $\mu$ 以下の開気孔十閉気孔が測定できる.

(3)プラスチシン法プラスチシンで焼結鉱を被覆し て(1) と同様に算出する気孔率 $\left(\varepsilon_{2}\right)$ で大気孔まで測定で きる.

\section{3. 還元性状測定法}

\section{$3 \cdot 1$ 低温還元粉化試験}

$15 \sim 20 \mathrm{~mm}$ の焼結鉱 $500 \mathrm{~g}$ をとり， $550^{\circ} \mathrm{C}$ で 30 min 還元する．これを常温で小型回転強度試験機(130

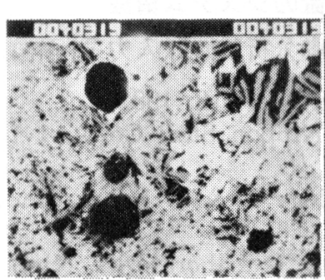

Microscopic feature

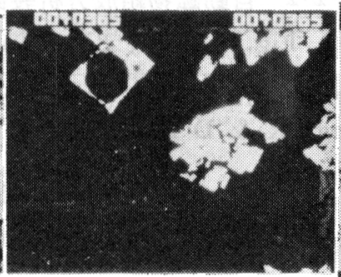

Hematite

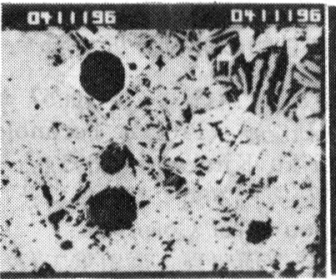

Hematite + magnetite $+\mathrm{Ca}$-ferrite

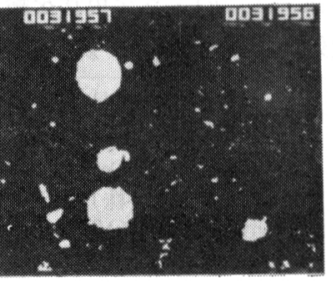

Pore

Photo. 1. Characteristics of detected image of mineral components. 
$\mathrm{mm} \phi \times 200 \mathrm{~mm}$ ) にかけ 900 回転させたのちの $3 \mathrm{~mm}$ 以 下の粉率 (RDI) をもつて指数值とする. 還元ガス, 還 元装置は還元試験に準ずる.

\section{$3 \cdot 2$ 還元試験}

JIS-M8713 に準ずる. $20 \pm 1 \mathrm{~mm}$ の焼結鉱 $500 \mathrm{~g} を$ $900^{\circ} \mathrm{C}$ で $180 \mathrm{~min}$ 還元したときの酸素除去率 (RI) と する.

\section{$3 \cdot 3$ 荷重軟化試験 15$)$}

$10 \pm 1 \mathrm{~mm}$ の焼結鈗を約 $500 \mathrm{~g}$ とり，荷重下で 1400 ${ }^{\circ} \mathrm{C}$ までの昇温還元試験を行い, 試料層の収縮率 (Sh) とガス圧損 $(A P)$ を指数值とする. 昇温速度は 200 $800^{\circ} \mathrm{G}$ で $10^{\circ} \mathrm{C} / \mathrm{min}, 800 \sim 1200^{\circ} \mathrm{C}$ で $2^{\circ} \mathrm{C} / \mathrm{min}, 1200$ $\sim 1400^{\circ} \mathrm{C} / \mathrm{min}$ で $5^{\circ} \mathrm{C} / \mathrm{min}$ とする. 荷重は $1 \mathrm{~kg} / \mathrm{cm}^{2}$ で $800 \sim 1400^{\circ} \mathrm{C}$ の温度域で加える.な打試料るつぼは $70 \mathrm{~mm} \phi$ で試料層高も $70 \mathrm{~mm}$ とする. 還元がスは 30 $\% \mathrm{CO}-70 \% \mathrm{~N}_{2}$ のものを $20 \mathrm{~N} l / \mathrm{min}$ の流量で供する.

\section{4 溶蜰滴下試験16)}

$10 \pm 1 \mathrm{~mm}$ の焼結鉱 $260 \mathrm{~g}$ をJIS の還元試験装置を用 いて還元率 $95 \%$ 以上に子備還元する. このために還元 ガスとして $40 \% \mathrm{CO}-60 \% \mathrm{~N}_{2}$ のものを $15 \mathrm{l} / \mathrm{min}$ で供す る. 還元条件は $1000^{\circ} \mathrm{C}, 180 \mathrm{~min}$ である. 予備還元し た試料 $200 \mathrm{~g}$ を $48 \mathrm{~mm} \phi$ のるつぼにつめて $1200^{\circ} \mathrm{C} \sim$ $1550^{\circ} \mathrm{C}$ まで昇温還元する。昇温は $1200^{\circ} \mathrm{C}$ までは $\mathrm{N}_{2}$ 雾囲気中で, $1200^{\circ} \mathrm{G}$ 以上は $\mathrm{CO}$ ガス $(2 \mathrm{Nl} / \mathrm{min})$ 中 で, $5^{\circ} \mathrm{C} / \mathrm{min}$ で行う. $1400^{\circ} \mathrm{C}$ を超えると試料の 1 部 が溶融してるつぼから滴下する. この滴下を開始する温 度 $\left(T_{\mathrm{d}}\right)$ を指数值とする. 滴下試料は $5 \sim 50^{\circ} \mathrm{C}$ 間隔で 採取し, 冷却後スラグとメタルに分離し, 必要ならば分 析する.

\section{4. 試料}

試料としてある時期の当社の焼結工場の焼結鉱 9 種を 選んだ.これらの化学組成を Table 1 に示す。これら

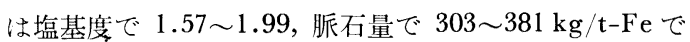

Table 1. Ghemical composition of samples.

\begin{tabular}{|c|c|c|c|c|c|c|c|c|c|}
\hline Sample & T. $\mathrm{F}_{\mathrm{e}}$ & $\mathrm{FeO}$ & $\mathrm{CaO}$ & $\mathrm{SiO}_{2}$ & $\mathrm{~A}_{\ell}{ }_{2} \mathrm{O}_{3}$ & $\mathrm{MgO}_{\mathrm{gO}}$ & $\begin{array}{l}\text { gangue* } \\
\text { M.P. }\end{array}$ & $\frac{\mathrm{CaO}}{\mathrm{SiO}_{2}}$ & $\begin{array}{c}\mathrm{S}, \mathrm{V},{ }^{* *} \\
(\mathrm{~kg} / \mathrm{t} \cdot \mathrm{Fe})\end{array}$ \\
\hline Sinter A & 58.03 & 7.25 & 9.05 & 5.76 & 1.90 & 0.86 & 1770 & 1.57 & 303 \\
\hline " B & 57.18 & 7.04 & 9.60 & 5.52 & 1.74 & 1.53 & 1810 & 1.74 & 322 \\
\hline " & 56.97 & 7.83 & 9.15 & 5.66 & 1.95 & 1.26 & 1790 & 1.62 & 316 \\
\hline " & 56.62 & 9.05 & 10.05 & 5.72 & 1.99 & 1.82 & 1800 & 1.76 & 346 \\
\hline " & 57.32 & 10.13 & 9.65 & 5.84 & 1.82 & 1.58 & 1760 & 1.65 & 303 \\
\hline " & 56.62 & 7.90 & 9.75 & 5.60 & 1.90 & 1.58 & 1820 & 1.74 & 333 \\
\hline G & 57.32 & 6.61 & 9.40 & 5.60 & 1.90 & 1.30 & 1810 & 1.68 & 318 \\
\hline " & 56.08 & 6.69 & 11.16 & 5.62 & 1.87 & 1.72 & 1870 & 1.99 & 363 \\
\hline " & 55.49 & 6.18 & 11.44 & 6.09 & 1.93 & 1.66 & 1860 & 1.88 & 381 \\
\hline
\end{tabular}

* Estimation from $\mathrm{CaO}-\mathrm{SiO}_{2}-\mathrm{Al}_{2} \mathrm{O}_{3}-\mathrm{MgO}$ phase diagram

** $\quad\left\{\left(\mathrm{CaO}+\mathrm{SiO}_{2}+\mathrm{Al}_{2} \mathrm{O}_{3}+\mathrm{MgO}\right) / \mathrm{T} \cdot \mathrm{Fe}\right\} \times 100$

ありまた原料，製造条件を異にしているから，実用焼 結鉱としては，いろいろな性状のものを選んだことにな る.

\section{5. 実 験 結 果}

\section{$5 \cdot 1$ 焼結鉱の鉱物組成}

試料とした 9 種の焼結鉱の鉱物組成測定結果を Table 2 に示す.これには同時に 3 種の気孔率の測定結果も示 した.これと Table 1 に示した化学組成との関係を見 ると Fig. 2 のよらになる. $\mathrm{FeO}$ 量とマグネタイト量, $\mathrm{CaO}+\mathrm{SiO}_{2}+\mathrm{Al}_{2} \mathrm{O}_{3}+\mathrm{MgO}$ 量と $\mathrm{Slag}$ 量などこれまで 化学組成から推定可能と考えられていたものの間にはか ならずしも明確な関係が認められない。塩基度とカルシ ウムフェライト量の間には本報の範囲で直線的な関係が 認められる. スラグ量は塩基度 1.7 前後までの範囲では 増加し, これ以上では急減している. D. JEULIN ら ( $^{8)}$ 塩基度の異なる焼結鉱を実験室的に製造し，塩基度の上 昇とともにカルシウムフェライト量が増加することを塩 基度 1.5 から 2.0 にかけてスラグ量が減少することを 報告している，松野17) は $\mathrm{Fe}_{2} \mathrm{O}_{3}-\mathrm{CaO}-\mathrm{SiO}_{2}$ 系での鉱物 生成状況を試薬を用いて，大気雲囲気下で調査し，次の ことを報告している．すなわち $1280^{\circ} \mathrm{C}$ 以上の温度域

Table 2. Mineral composition and porosity of samples.

\begin{tabular}{|c|c|c|c|c|c|c|c|c|}
\hline Sample & hematite* & magnetite* & Ca-forrite* & $\operatorname{slag} *$ & pore & $\varepsilon_{0}$ & $\varepsilon_{1}$ & $\varepsilon_{2}$ \\
\hline Sinter $A$ & 35.8 & 24.0 & 26.2 & 14.0 & 21.2 & 14.4 & 26.0 & 31.6 \\
\hline " & 22.1 & 20.5 & 40.3 & 17.1 & 23.1 & 14.4 & 16.7 & 33.0 \\
\hline " $\quad \mathrm{C}$ & 24.6 & 26.0 & 31.7 & 17.7 & 22.1 & 12.2 & 15.0 & 32.3 \\
\hline "1) & 26.1 & 26.8 & 34.4 & 12.9 & 23.5 & 15.7 & 20.9 & 30.7 \\
\hline " $\mathrm{E}$ & 23.2 & 23.6 & 36.3 & 17.0 & 18.0 & 14.1 & 17.2 & 41.0 \\
\hline " $\mathrm{F}$ & 21.4 & 29.2 & 33.6 & 15.8 & 24.0 & 17.6 & 21.5 & 34.8 \\
\hline " (i) & 27.4 & 20.1 & 32.9 & 19.6 & 25.0 & 15.1 & 19.5 & 44.7 \\
\hline " H & 13.7 & 22.3 & 49.3 & 14.7 & 19.5 & 11.5 & 15.0 & 31.6 \\
\hline "I I & 30.4 & 13.3 & 42.4 & 14.0 & 20.8 & 13.0 & 12.8 & 28.3 \\
\hline
\end{tabular}

* hematite + magnetite + Ca-ferrite + slag $=100 \%$ 

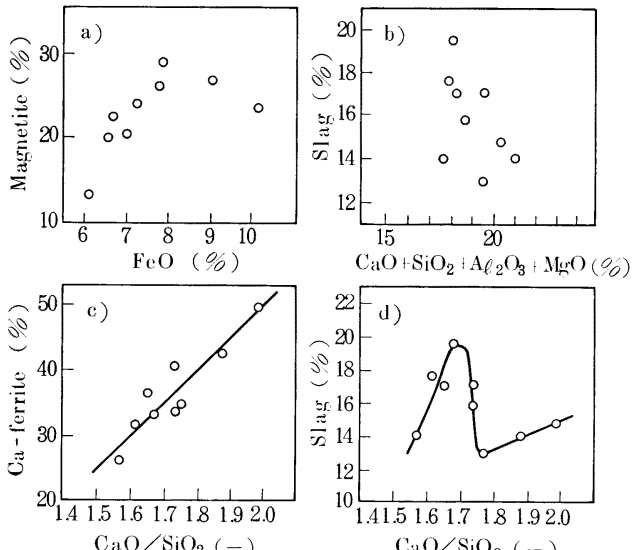

Fig. 2. Relationship between mineral composition and chemical composition.

では塩基度 1.86 を境にして，これ以上ではカルシウム フェライトが，またこれ以下ではスラグが生成するが, $1200 \sim 1280^{\circ} \mathrm{C}$ の温度域では塩基度 $1.4 \sim 2.0$ ではへマ タイト，カルシウムフェライトおよびスラグの混合体に なる. 本報での調査結果はカルシウムフェライト量と スラグ量の動きについては JEULIN らの結果と同一であ り，また実機焼結鉱であるから試薬より反応が遅く非平 衡であつたとすれば, 塩基度 1.86 以下でもカルシウム フェライトが, また塩基度 1.86 以上でもスラグが存在 する本報の結果は松野のそれとも矛盾しない.

このよらに化学組成と鉱物組成の間にはかならずしも 一定の関係がなく，化学組成から焼結鉱中の鉱物組成を 推定するのは難しいものと考えられる.

\section{2 焼結鉱の還元性状と組織}

焼結鉱の還元性状試験結果を Table 3 に示す. RDI は 24〜 42, RI は 57〜 72 と実用焼結鉱の範囲では大き な差異をもつものである. この結果と化学組成の関係を Fig. 3 飞示与. 溶融滴下試験の $T_{\mathrm{d}}$ と塩基度以外に良

Table 3. The results of reduction property tests.

\begin{tabular}{|c|c|c|c|c|c|c|}
\hline & \multirow{2}{*}{\begin{tabular}{|l|} 
Roluction \\
degra- \\
dation \\
index \\
$(0)$ \\
\end{tabular}} & \multirow[b]{2}{*}{$\begin{array}{c}\text { Degree of } \\
\text { reduction } \\
(\%)\end{array}$} & \multicolumn{2}{|c|}{ Soltening property } & \multicolumn{2}{|c|}{ Mcll -down projerty } \\
\hline & & & \begin{tabular}{|l|}
$\begin{array}{l}\text { Pressure } \\
\text { drop }\end{array}$ \\
$\left(m \mathrm{H}_{2} \mathrm{O}\right)$ \\
\end{tabular} & $\begin{array}{c}\text { Shrinkage } \\
(\%)\end{array}$ & $\begin{array}{l}\text { Degree of } \\
\text { pre- } \\
\text { reduction } \\
(0)\end{array}$ & 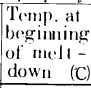 \\
\hline Sinter A & 33.6 & 57.9 & 66 & 47.6 & 98.0 & 1510 \\
\hline " B & 42.0 & 71.9 & 87 & 50.0 & 96.0 & 1480 \\
\hline " C & 28.7 & 57.4 & 114 & 52.8 & 98.6 & 1510 \\
\hline "D & 37.9 & 63.1 & 57 & 47.3 & 97.0 & 1505 \\
\hline " E & 32.1 & 64.4 & 72 & 45.0 & 95.9 & 1518 \\
\hline $\mathrm{F}$ & 24.3 & 63.3 & 73 & 49.8 & 101.6 & 1497 \\
\hline $\mathrm{G}$ & 41.1 & 64.7 & 87 & 50.1 & 95.9 & 1507 \\
\hline $\mathrm{H}$ & 32.7 & 61.4 & 61 & 45.7 & 96.4 & 1445 \\
\hline I & 34.5 & 56.9 & 75 & 49.9 & 97.8 & 1448 \\
\hline
\end{tabular}
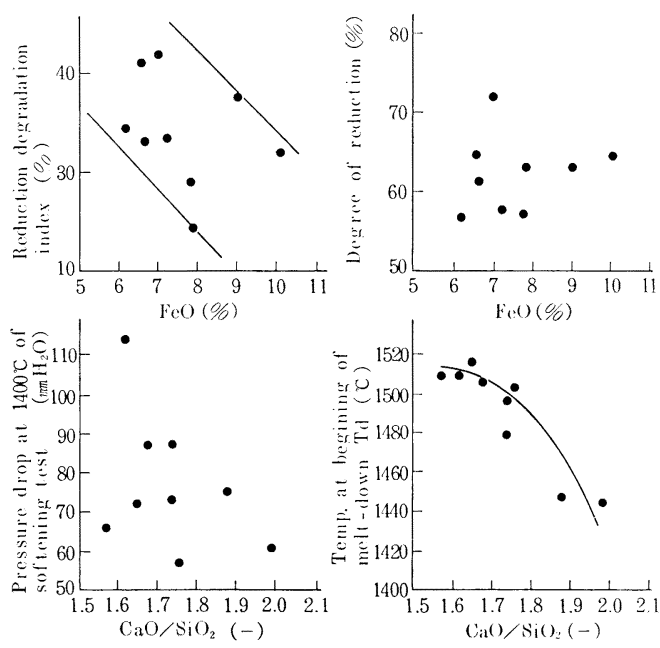

Fig. 3. Relationship between chemical composition and reduction property of samples.

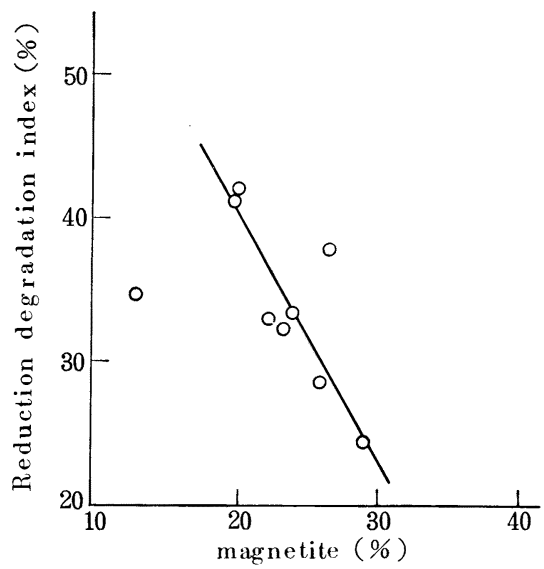

Fig. 4. Relationship between reduction degradation index and quantity of magnetite.

い相関関係は見られない.

そこで鉣物組成，気孔率と還元性状の関係を見るため に Table 2, Table 3 のデータを用いて重问忬分析を 行い，寄与率の高い要因を選びだすこととした。

まず RDI については Fig. 4 に示すようにマグネタ イトとの関係が認められる. 焼結鉱の低温還元粉化は 焼結過程で生成する 2 次のへマタイトが原因とされてい $ろ^{18)}$.

本報の测定では反射輝度のみで鉱物の識別を行つたの で, 鉱石が未溶融で残る 1 次へマタイトと 2 次へマタイ トの判別ができず RDI とへマタイト量の関係が見られ なかつたものと考光られる.ただ 2 次へマタイトはマグ ネタイトに由来するという従来の研究結果からすれば, 
酸化鉄鉣物がマグネタイト段階により多く止まつている ものは2 次生成のへマタイトの生成が少ないものと考古

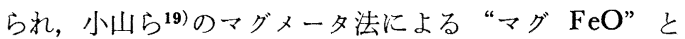
RDI の関係を示した報告とも一致する.

次に JIS 法による被還元性については重回帰分析で有 意となる要因は見いだされなかつたが，Fig. 5 に示す 非線型の関係が見られた．これから被還元性の高い燒結 鉱とはカルシウムフェライト量と $500 \mu$ 以下の気孔率,

$\varepsilon_{1}$ の大きい構成のものと考兄られる.

さらに荷重軟化性として $\Delta P$ と組織の関係を Fig. 6 に示す。これは高度に有意な関係で， $\Delta P$ を減少させる にはスラグ量を減少させ，全気孔率を増加させればよい ことがわかる.

最後に溶融滴下性として $T_{\mathrm{d}}$ と組織の関係を Fig. 7

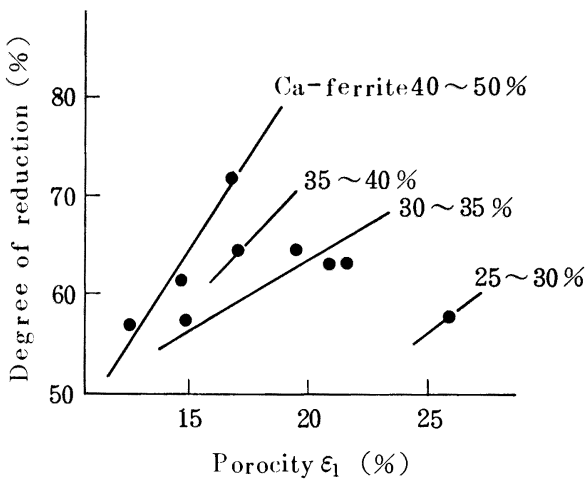

Fig. 5. Relationship between degree of reduction and quantity of calciumferrite, porosity.

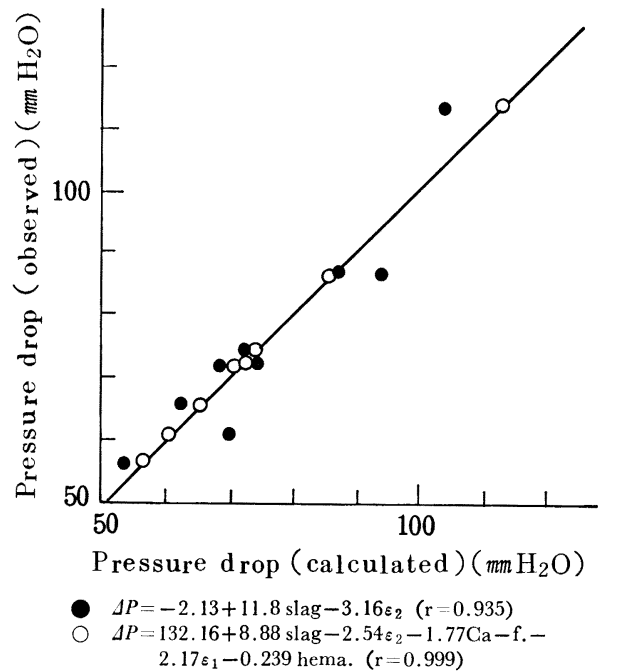

Fig. 6. Multiple correlation on pressure drop at $1400^{\circ} \mathrm{C}$ of the softening test under load.

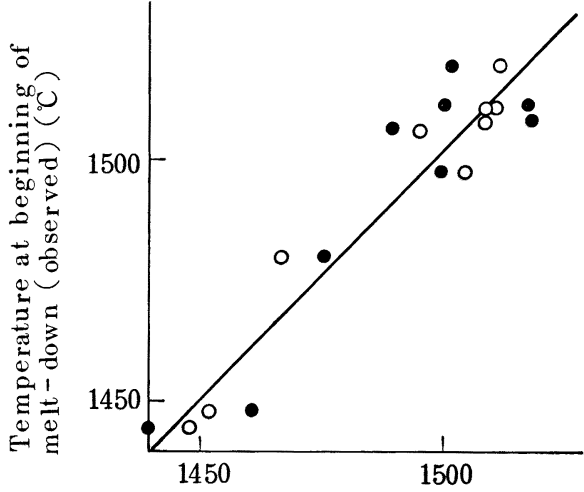

Temperature at beginning of melt-down (calculated) ( ${ }^{\circ} \mathrm{C}$ )

Tdrop $=1546.3-3.15 \mathrm{Ca}-\mathrm{f} .+1.74 \varepsilon_{2} \quad(\mathrm{r}=0.919)$ Tdrop $=1233.3-0.152 \mathrm{Ca}-\mathrm{f} .+2.88 \varepsilon_{2}+5.51 \mathrm{mag}$. $-2.61 \varepsilon_{1}+3.47$ hema. $(r=0.968)$

Fig. 7. Multiple correlation on temperature at beginning of melt-down.

に示す。これも高度に有意な関係で $T_{\mathrm{d}}$ を高めるにはカ ルシウムフェライト量が少なく, 全気孔率の高いものが よい。

このように焼結鈗の還元性状と組織との関係は化学組 成との関係よりも有意な相関関係を示すことが多く，イ メージがより具体的である点に特徵がある20).

\section{6. 考}

察

前章で焼結鉣の還元性状と組織の統計的な関係につい て述べたが，単なる統計的な関倸にとどまる限り，将来 とも有効な指標として活用できるものか，現象の一時的 局所的な説明にとどまるものか明らかでない，少なくと も焼結鉱還元時の挙動が組織との関係で理解できること が望ましい。ここでは以上のような観点からいくつかの 検討を行つた.

\section{1 低温還元粉化}

低温還元粉化の原因となる 2 次へマタイトは特徴ある 形態を示すことが報告されている．これを画像処理して 指数化すれば直接 2 次へマタイト量が定量できるが，現 状ではいまだそのレベルに到達していない，ただ詳細に 1 次， 2 次のへマタイトを観察すると，その粒度に差が 認められる. 未溶融で残る 1 次へマタイトは通常 $500 \mu$ 以上の粒子として存在することが多い，そこで焼結鉱 $\mathrm{G}$ について 層高方向から $4 \sim 8$ 個の試料を採取し，粒子 径別のへマタイト量と RDI の関係を見た。そ結果 Fig. 8 に示すように 100〜300 $\mu$ の粒子径のへマタイト (粒子数) と RDI の間に明瞭な関係が認められた。 ただ $100 \mu$ 以下の粒子径のへマタイト量は RDI と一定の関 


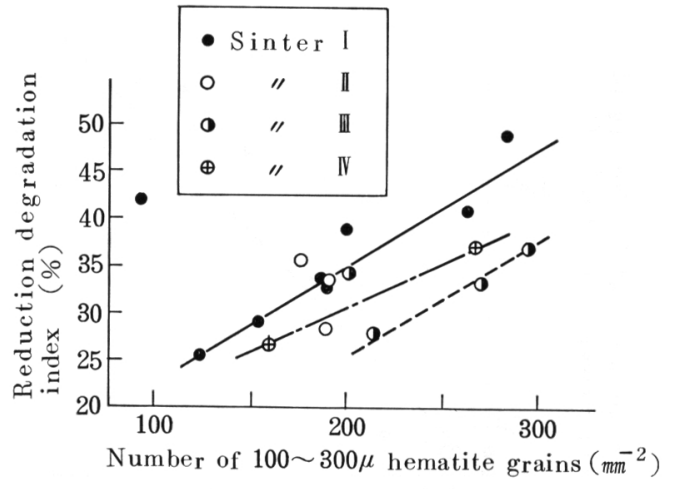

Fig. 8. Relationship between reduction degradation index and number of $100 \sim 300 \mu$ hematite grains.

係を示さない。この両者は形態的には同じ 2 次へマタイ トと観察されるので, 卆の差が何によるのか現在のとこ ろ明らかではない。

\section{2 被還元性}

焼結鉱の定温還元機構を明らかにするために，今回の 調査で RI に最も大きい差異のあつた焼結鉱 B と焼結鉱 I について還元過程の組織観察を行つた. Photo. 2 に 還元前焼結鉱の溶解部の組織を示す。焼結鉱 B は微細な 針状カルシウムフェライトと気孔が多く, 焼結鉱 I では カルシウムフェライトは長柱状で, 組織全体にスラグが 発達している.

次に還元時の組織観察の結果について述べる.

（1）焼結鉱粒子はマク口的には外款部から内芯部へ 還元が進行するが，ペレットのようにトポケミカルな還 元にならないのは反応界面が広い，いわゆるZ Zonal な 還元形態になつているからである.

（2）ミクロ的にはトポケミカル還元部分と均一還元 部分が混在している.

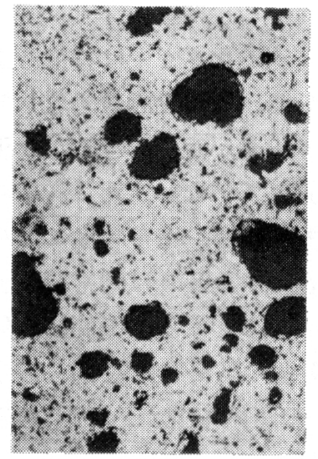

Sinter B

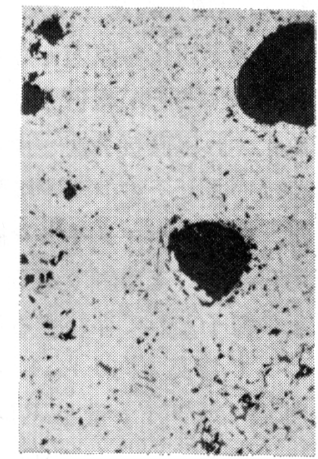

Sinter I $200 \mu$
Photo. 2. Microstructures of melted part in sinters.

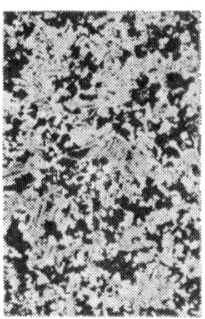

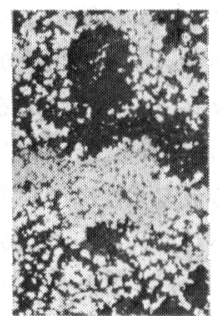

Ca-ferrite

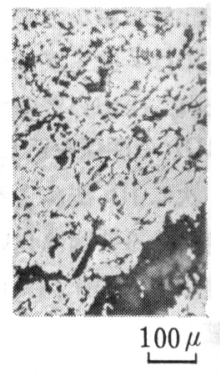

Non-melted ore white : metallic iron, grey : wustite

Photo. 3. Microstructures of sinter reduced at $900^{\circ} \mathrm{G}$.

（3）構成鉱物と還元形態の間には次の対応がある. 典型的な例を Photo. 3 に示す.

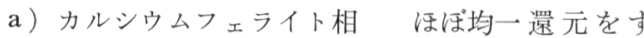

b ）スラグーマトリックス相林ケミカル還元と なる。

スラグーマトリック スが発達した部分で は例えカルシウムフ ェライトでも還元が 遅れる.

c）未溶融鉱石部叔ヶミカル還元と なる。

d）大気孔部

還元が進行している 部分もあるが全体の 特徴ではない。

焼結鉱の被還元性は均一還元部分とトポケミカルな還 元部分の割合で決まり均一還元部分の多いものほど RI は高い. 均一還元する領域は構成鉱物ではカルシウムフ ェライトであり Fig. 5 に示した結果が説明でさる。さ らに両焼結鉱の差としてスラグーマトリックス発達の有 無が挙られる. $\varepsilon_{1}$ はこの差を表しているものと考光られ る.

\section{3 荷重軟化性}

Fig. 6 で示したように $\Delta P$ はスラグ量と $\varepsilon_{2}$ でほとん ど説明できる. スラグは還元過程で $\mathrm{FeO}$ と $\mathrm{CaO}$ の交 換を行らことにより高融点化するが，もともとスラグ自 身の融点は低いので軟化原因になる， $\varepsilon_{2}$ については次 のように考觉られる。ペレットの場合 $A P$ には高温の 被還元性が影響し，たと光ぱ RI の点ではペレットの中 でも良好なコールド・ペレットでも粒径を大きくすると Fig. 9 に示すように $\Delta P$ は増加する，ところが焼結鉱 では粒径を変えても $\Delta P$ はほとんど変化しない.ペレッ 


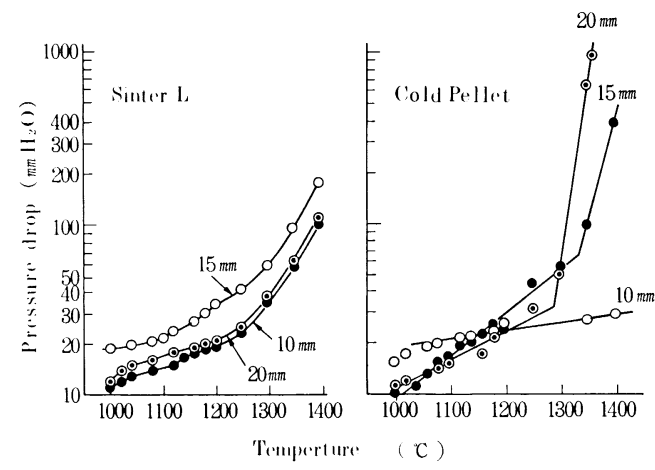

Fig. 9. Characteristics of softening under load of pellets and sinters.

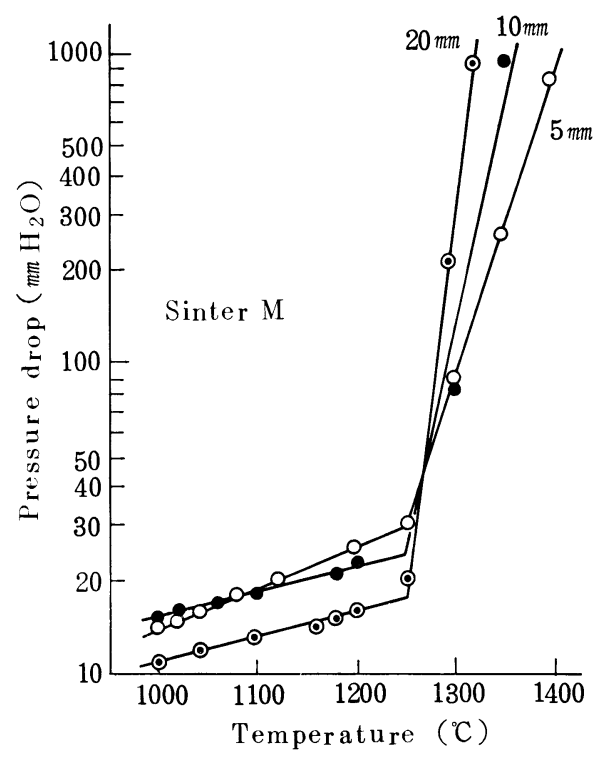

Fig. 10. Charateristics of softening under load of sinter $\mathrm{M}$.

トの場合は良く知られているよらに精子が全体としてト ポケミカルな還元をするために中核部に $\mathrm{FeO}$ や低融点 スラグが残り，高温になると溶融して軟化原因となる21). 焼結鉱の場合にはトポケミカル還元領域はミクロ的に粒 子中に分散しており,さらに高温になつても還元の進行 が持続する. この還元の進行に焼結鉱特有の大気孔が重 要な役割を果たしているものと考劣られる，実験室的に 燃料多量添加によつて $\varepsilon_{2}$ の小さい, 緻密な焼結鉱を製 造して試験をすると, その焼結鉱の $\Delta P$ は Fig. 10 に 示すよらにペレットと同じ挙動を示すことからも $\varepsilon_{2}$ の 役割がわかる.

\section{4 溶融滴下性状}

本報で採用した試験法では Table 3 に示すように予

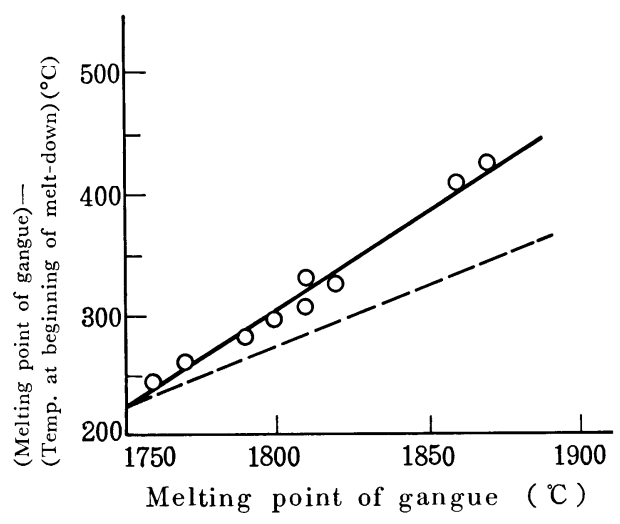

Fig. 11. Relationship between the difference (melting point of gangue-temperature at beginning of melt-down) and melting point of gangue.

備還元率が高いために原組織の影響は小さくなる。この ようなメタルへの浸炭で $T_{\mathrm{d}}$ が決まる場合には脈石融点 の影響が大きく，それが $1700^{\circ} \mathrm{C}$ を超えるときはその 上昇とともに $T_{\mathrm{d}}$ は低下する ${ }^{16)}$. 本報の場合も $T_{\mathrm{d}}$ と脈 石融点の関係は Fig. 11 に示すように従来の結果と一 致している. 焼結鉱の場合, 脈石融点は塩基度に依存す るところが大きいし，Fig. 2 に示すようにカルシウム フェライト量も塩基度に比例している．したがつて $T_{\mathrm{d}}$ へのカルシウムフェライト量の影響は疑相関であり, 本 当は脈石融点の影響と考えるのが妥当であろう． $\varepsilon_{2}$ は 構造的な要因としてメタル中への浸炭速度を低下させ, $T_{\mathrm{d}}$ 上昇の効果をもたらしているものと考えられる.

\section{7. 結言}

焼結鉱の鉱物組成および気孔率の定量法を開発し, 焼 結鉙の還元性状を構成鉱物と気孔構造とから理解し，望 ましい焼結鉱の組織イメージを明確にするために検討を 行つた. その結果焼結鉙組織と還元性状の間には以下に 示寸密接な関係があることがわかつた。

(1) RDI は $100 \sim 300 \mu$ の粒子径のヘマタイト量 によつて表される.

(2) RI はカルシウムフェライト量と $500 \mu$ 以下の 気孔率とで決まり, 両者が増せば向上する.

（3）荷重軟下性はスラグ量と全気孔率とに関係し, スラグ量が小さく，全気孔率が大きくなるほど圧損は下 がる.

（4）溶融滴下性は還元がほとんど終了している段階 での試験で原組織との直接的な結びつきは少ない. 力 ルシウムフェライト量は小さく, 全気孔率が大きいほど 
$T_{\mathrm{d}}$ は上昇する。このときのカルシウムフェライト量は 脈石融点を表している.

これらは単に統計的な関係のみでなく, 還元過程の検 討に裏づけられており, 今後とも有効な指標として活用 できるものと考兄られる，また化学組成から焼結鉱組織 を推定するのには無理があり,さらに焼結鉱の還元性状 も, 溶融滴下性を除いては化学組成との関係で論ずべき ではないものと考兄られる，したがつて燒結鉱組織分析 の重要性はますます大きくなろう.

今後はさらに形態学 (Morphology) 的検討を進め, 常温強度を表現できるマクロ組織, 2 次へマタイト, 構 成鈗物の相互関係などを定量化することが望まれる。

\section{交献}

1) $P$. Lecomte and $R$. Vidal: GNRM, 23 (1970), p. 3

2) P. LeComte: GRM, 28 (1971), p. 25

3 ) 佐々木稔, 榎戸恒夫：製鉄研究，(1976） 288

4 ）佐々木稔，中沢孝夫：鉄と鋼，54 (1968), p. 1217

$5)$ D. A. Kissin and T. I. Litvinova: Stal in Eng., 5 (1960), p. 318

6 ) 小島鴻次郎, 永野恭一, 稻角忠弘, 高木勝博, 品 田功一：鉄と鋼, 55 (1969), p. 669

7 ）楊澈基, 正路徹也, 武内寿久襦：日本鉱業会誌, 93 (1977), p. 411
$8)$ D. Jeulin, $J . L$. Letailleur, and $M$. SCHNEIDER: Proc. of the 2nd International Symp. on Agglomeration (1977), p. 526

9 ) $A$. Greco, $D$. Jeulin, and $J$. Serra: J. Microsc., 116 (1978), p. 199

10) $T$. Hersant, $D$. Jeulin, and $P$. Parniere: IRSID report. RE 322 (1975)

11) C. LE. Corre, B. Kayser, J. C. Celessi, and $D$. Jeulin: Reprint from "Agglomeration 81" Nürnberg, 6-8. 5 (1981)

12）渋谷悌二, 丹羽康夫, 谷中秀臣, 照井健二, 山用 健夫，上杉满昭：鉄と銅，67 (1981)，S98

13) 啮谷悌三, 斎藤 沉, 谷中秀臣, 竹元 寞, 山田 健夫，上杉満昭：鉄と鋼，67 (1981)，S679

14）須賀田正泰, 梅津善德, 山口一表, 斎滕元治, 下 沢栄一：鉄と鋼, 67 (1981), S 680

15）釜勝也, 肥田行博, 重見彰利, 児玉惟菜: 鉄之 鋼, 61 (1975), p. 777

16) 交勝也, 山口一良, 重見暗利, 西时信直, 神原 健二郎：鉄と鋼, 65 (1979), p. 505

17）松野二三朗：鉄と鋼，64 (1978), p. 1499

18）佐々九稔，榎戸恒夫，近藤直…, 小沢孝夫：鉄之 鋼，59 (1973), p. 1209

19）小山朝良, 山本一博, 花木幸肾, 矢間菜一, 広島 龍夫：鉄と鋼， 64 (1978), S 480

20) 鈴木 悟, 佐藤勝㦄, 爷勝也, 千々和九州男, 江口清美：鉄と鋼，67 (1981)，S 96

21）成田貴一，前田㒶大：鉄と鋼，63 (1977), p. 1443 